\title{
Announcements Effect of Corporate Bond Issuance and Its Determinants
}

\author{
Sze Kim Chin' \& Nur Adiana Hiau Abdullah²
}

ABSTRACT This study aims to investigate the effect of bond issuance announcements and to determine the
company characteristics that could influence this effect. The findings reveal positive cumulative
average abnormal returns following bond issuances, indicating that the market considers bond
offers to be favorable news. Nevertheless, cross-sectional regression analysis shows an insignifi-
cant relation of company profitability, growth opportunities, asset tangibility, size, and managerial
ownership with cumulative abnormal returns. The results confirm that there is a signaling effect of
bond issuance announcements and that this effect is not affected by company characteristics.

KEY WORDS: bond, equity market behavior, event study

JEL Classification: G11, G32, G14

${ }^{1}$ INTI International University, Malaysia, ${ }^{2}$ Universiti Utara Malaysia, Malaysia

\section{Introduction}

In the past, companies in many emerging countries were interested in borrowing from banks (Luengnaruemitchai \& Ong, 2005). However, the interest rate charges of banks are relatively high, and they are usually reluctant to issue loans with long maturities (Eichengreen, 2004). As an alternative, companies can issue long-term bonds at low interest rates (Navarrete, 2001) and deduct interest payments as business expenses. The investigation of bond offerings to the public has been an interesting area of academic corporate finance research because bonds are gradually becoming an important corporate financing alternative.

According to a report by the Bank for International Settlement (2007), long-term interest rates may not be competitively determined and thus may not reflect the 믄 true cost of funds in economies lacking well-developed

Correspondence concerning this article should be addressed to: Nur Adiana Hiau Abdullah, School of Economics, Finance and Banking, College of Business Universiti Utara Malaysia, 06010 UUM Sintok, Kedah, MALAYSIA, e-mail: diana897@uum.edu.my local currency bond markets. Hence, the concerted development of local currency bond markets has become a major objective of financial policy in many parts of the world. Well-functioning capital markets are fundamental for sustainable growth. In particular, deep and liquid local currency bond markets play a key role in the financial stability and economic development of a country. They ensure greater access to capital across an economy, provide stability and diversification of savings and investments, and reduce the economy's susceptibility to external shocks.

In the 1970s, the Malaysian government started issuing bonds to meet the massive funding needs of the country's development projects; this marked the start of the Malaysian debt securities market. In the mid1980s, the Malaysian government further developed the corporate debt market due to the over-reliance of the private sector on bank borrowings. The National Mortgage Corporation, Cagamas Bhd, was set up to provide liquidity assistance to banks so that affordable housing loans could be extended by the central bank or Bank Negara Malaysia (BNM) in December 
Table 1. Funds raised in the capital markets and banking system

\begin{tabular}{ccccc}
\hline Year & $\begin{array}{c}\text { New issues of Bonds } \\
\text { (RM million) }\end{array}$ & $\begin{array}{c}\text { Borrowings from } \\
\text { Banking system (RM } \\
\text { million) }\end{array}$ & $\begin{array}{c}\text { New issues of Equities } \\
\text { (RM million) }\end{array}$ & $\begin{array}{c}\text { Total Funds } \\
\text { (RM million) }\end{array}$ \\
\hline 2001 & $37,932(63 \%)$ & $16,100(27 \%)$ & $6,124(10 \%)$ & $60,156(100 \%)$ \\
2002 & $36,195(52 \%)$ & $19,800(29 \%)$ & $13,291(19 \%)$ & $105,481(100 \%)$ \\
2004 & $51,853(64 \%)$ & $21,600(26 \%)$ & $7,772(10 \%)$ & $81,225(100 \%)$ \\
2005 & $36,340(44 \%)$ & $40,200(48 \%)$ & $6,475(8 \%)$ & $83,015(100 \%)$ \\
2006 & $38,196(76 \%)$ & $5,790(11 \%)$ & $6,315(13 \%)$ & $50,301(100 \%)$ \\
2007 & $38,887(76 \%)$ & $10,011(20 \%)$ & $1,916(4 \%)$ & $50,814(100 \%)$ \\
\hline
\end{tabular}

Source: Bank Negara Malaysia annual report (2005; 2006; 2007)

of 1986. This was the first step in developing the debt securities market in this country. The bond market in Malaysia further gained attention in 1990s, when conventional bank borrowing was found to be inadequate for funding long-term infrastructure and development projects by the private sector. The Malaysian government therefore increased its effort to develop corporate bond markets in order to offer the private sector an alternative source of financing and with the hope of helping to reduce funding mismatches (Ibrahim \& Wong, 2005).

The development of the bond market from an inactive to a developing market can be seen in Table 1, which shows that the bond market is becoming a larger source of borrowed funds than the banking system and the equity market. More than $50 \%$ of the funds in the capital markets and banking system were raised through the issuance of bonds, whereas less than $30 \%$ were raised from bank borrowings (except in 2004) and less than $20 \%$ were raised from equity issues.

As the bond market becomes the major source of funds, there is a possibility that it could affect the equity market. As noted by Gebhardt, Hvidkjaer, and Swaminathan (2005), bonds and stocks have the same underlying operating cash flows and are affected by the same company fundamentals. Therefore, bonds cannot evolve independently of equities. Thus, some correlations between bonds and equity market behavior are expected. However, there is still little research in this area. The present study aims to address the impact of bonds on the equity returns of the issuing compa- nies, which still an under-researched subject, especially in emerging markets such as Malaysia. Thus far, mixed results were found by those who have attempted to explore this subject matter, such as Kapoor and Pope (1997) and Lewis, Rogalski and Seward (2001) in the US market, Abhyankar and Dunning (1999) in the UK market, Schramade (2005) in the Dutch market, Carlsson, Holm, and Sello (2006) in the European markets, and Martel and Padron (2006) in the Spanish market. Hence, research analyzing the bond issuance effect on share price performance and examining the cross-sectional determinants of this effect for listed companies in Malaysia is needed.

The following section presents a literature review of underlying theories and prior empirical evidence, followed by the research design in section three. The analysis of the results is subsequently presented in section four. Finally, section five concludes the study and suggests some possible future research areas.

\section{Underlying theories and empirical evidence on the effect of bond issuance and its determinants}

According to Lewis et al. (1999), corporate events often lead to changes in the trading activities of a company's common stock. Though Fama and French (1998) argue that a company's financing decisions have no effect on its market value and thus that security holders are indifferent to debt versus equity financing, their argument relies entirely on the existence of a perfect capital market and assumes that companies 

spectively. Stein (1992) stated that company size could be considered to be a proxy of the degree of information asymmetry because larger companies are more likely to have greater analyst coverage and to undergo greater scrutiny by institutional investors. In addition, company size could also be a proxy of financial distress costs. In either case, cumulative abnormal returns are expected to be positively related to company size. On the other hand, several previous empirical works investigating the impact of size did not find any correlation with investor reactions, including De Roon and Veld (1998), Abhyankar and Dunning (1999), Lewis et al. (1999, 2003), and Ammann et al. (2006).

Brennan and Kraus (1987) and Brennan and Schwartz (1988) suggested that announcement period abnormal returns were negatively related to credit quality and firm value but positively related to investment policy, whereas Green (1984) showed that announcement period abnormal returns will be positively related to future growth opportunities after controlling for differences in corporate investment policy shifts and underinvestment. This is further supported by Lewis et al. (1999), Dutordoir and Van de Gucht (2004), and Chen et al. (2005). However, Mollemans (2002) and Arshanapalli et al. (2004) observed a significant negative impact whereas Abhyankar and Dunning (1999), Lewis et al. (2003), and Ammann et al. (2006) did not notice any significant relation. Bradley et al. (1984) proposed that companies with high sales growth rates often need to expand their capacity, implying that high growth companies have greater future needs for funds.

No significant influence of profitability was found by Lewis et al. (2003) in the US market and Dutordoir and Van der Gucht (2004) in Western Europe. In contrast, Stein (1992) found that profitability is inversely correlated with the probability of the occurrence of financial distress. Low profitability not only increases anticipated financial distress costs but also implies higher risk uncertainty and the greater probability of a shift to a riskier investment policy. Hence, a negative correlation is expected between the market reaction and the level of profitability.

Trade-off theory (Modigliani \& Miller, 1963) suggests that companies with more tangible assets can incur high debt because of their ability to provide sufficient collateral and security to lenders. Bradley, Jarrel, and Kim (1984) asserted that companies that heavily invest in tangible assets also have higher financial leverage because they can borrow at lower interest rates if their debt is secured with these types of assets. As such, companies with more tangible assets may have an advantage over smaller companies in accessing debt markets and borrowing under better terms and conditions (Ferri \& Jones, 1979; Wiwattanakantang, 1999).

According to agency theory, the principal-agent conflict can be mitigated by a larger ownership share held by managers. Jensen (1986) argues that the use of debt can reduce agency costs between managers and shareholders by reducing the 'free' cash available for managers to pursue their own interests. Therefore, companies with higher managerial ownership may not need to incur much debt financing because managers who own shares would most likely act towards increasing shareholder wealth. As noted by Jensen (1986), debt forces managers to disgorge cash rather than spend it on investments with negative net present values. This effect might be stronger for public debt than for private debt.

\section{Research design}

This study's sample comprises observations from public listed Malaysian companies during the eight consecutive years from 2000 to 2007. The main data sources are the Securities Commission of Malaysia, Bursa Malaysia, Bank Negara Malaysia, the Rating Agency of Malaysia, and the Malaysian Rating Agency Corporation. The annual reports of the sample companies were obtained from the Bursa Malaysia website and library and Datastream was used to extract market information.

The sample includes public debt issuances by companies that have no outstanding debt securities at the time of issuance. The study excludes private placement of debt issues. Of the 626 bond issuers that are listed on the Securities Commission of Malaysia website, the final data used in this study were reduced to 100 sample companies (issuers) after excluding non-public listed companies, financial institutions and insurance companies, and companies with other major corporate events such as bonus issuances, dividend announcements and stock splits, as well as those with missing data and outliers. Furthermore, to have clean data, companies with existing long-term debt on their balance sheets were also excluded.

Because it is quite common for companies to issue securities several times during one year, meaning that 

riod. For each sample security, the return on security $\mathrm{i}\left(\mathrm{R}_{\mathrm{i}, \mathrm{t}}\right)$ for time period t relative to the event is:

$\mathrm{R}_{\mathrm{i}, \mathrm{t}}=\mathrm{R}_{\mathrm{m}, \mathrm{t}}+\mathrm{e}_{\mathrm{i}, \mathrm{t}}$

where $\mathrm{R}_{\mathrm{m}, \mathrm{t}}$ is the market return at time $\mathrm{t}$, as calculated from a market portfolio or a market index, and $e_{i, t}$ is the component of returns that is abnormal or unexpected. The MAR model assumes that $\alpha=0$ and $\beta=1$. Given this return decomposition, the abnormal return, $\mathrm{e}_{\mathrm{i}, \mathrm{t}}$ is the difference between the observed return and the market return:

$e_{i, t}=R_{i, t}-R_{m, t}$

Equivalently, $e_{i, t}$ is the difference between the return that is conditional on the event and the expected return that is not conditional on the event or the market return. Thus, the abnormal return is a direct measure of the (unexpected) changes in company value and returns associated with the event.

Following MacKinlay (1997), the abnormal return observations must be aggregated to draw general inferences related to the event. The aggregation is made along two dimensions: through time and across stocks. The following average company-unique return, in this case the average abnormal return (AAR), is estimated for each day surrounding the issuance of bonds:

$$
A A R_{t}=\sum_{t=1}^{N} e_{i, t} / N
$$

where $\mathrm{AAR}_{t}$ equals the average abnormal return for the number of bond issues $\mathrm{N}$ examined in a given day $\mathrm{t}$. The calculation is performed for the whole event period of 60 days before and after the bonds offers. A ttest is then calculated for each event day to see whether there is a significant effect due to the bond offers. The AAR would then be summed throughout the event days to form the cumulative average abnormal return (CAAR) presented in equation (4):

$$
C A A R_{t}=\sum_{t=1}^{N} A A R_{t}
$$

It is expected that the value of CAAR is zero in the absence of abnormal performance. Hence, a t-statistic is performed on the pre- and post-issue estimates of the CAAR over different intervals surrounding the event period.

\subsection{Multiple regression technique}

To explain the reactions of investors to bond issues, previous studies have chosen to focus on the various company characteristics that presumably contribute to such reactions. There are a total of five independent variables used in this study: profitability, asset tangibility, company size, growth opportunities, and managerial ownership. Data for profitability, asset tangibility, company size, and managerial ownership are extracted from the annual reports of issuing firms one year prior to the bonds issuance whereas data for growth opportunities are taken from two years prior to the issuance. This is consistent with the methods employed in previous studies, such as Rajan \& Zingales (1995), Lee at al. (2000), Devic \& Krstic (2001), Hovakimian et al. (2004), Isachenkova \& Mickiewicz (2004), Pandey (2004), Buferna (2005), and Guha \& Kar (2006). The dependent variable used in this study is cumulative abnormal returns (CAR), which is obtained by summing up the abnormal returns of each of the 100 observation from day $t=-60$ to $t=+60$. The following regression model is used in the study:

$\mathrm{CAR}_{\mathrm{i}}=\alpha+\beta_{\mathrm{i} 1}$ SIZE $+\beta_{\mathrm{i} 2}$ PROFITABILITY + $+\beta_{\mathrm{i} 3}$ TANGIBILITY $+\beta_{\mathrm{i} 4}$ GROWTH $+\beta_{\mathrm{i} 5}$ OWNER $+\varepsilon$

where

Company size $[$ SIZE $]=$ Natural logarithm of total sales (Titman \& Wessel, 1988; Rajan \& Zingales, 1995; Devic \& Krstic, 2001; Gaud et al., 2005).

Profitability [PROFITABILITY] = Earnings before interest and taxes divided by total assets (Rajan \& Zingales, 1995; Gaud et al., 2005).

Asset tangibility [TANGIBILITY] $=$ Fixed assets plus inventory divided by total assets (Devic \& Krstic, 2001; Chen, 2004; Gaud et al., 2005).

Growth opportunities [GROWTH] = Annual sales growth rate (Titman \& Wessel, 1988; Chen, 2004).

Managerial ownership [OWNER] = Natural logarithm of ratio of directors' shares to total outstanding shares (Denis \& Mihov, 2003; Isachenkova \& Mickiewicz, 2004)

\section{Findings and discussion}

As seen in Table 2, profit margins range from $-55.5 \%$ to $19.5 \%$, with an average profit margin of $4.7 \%$ among the 100 sample companies. This variable has the lowest 
Table 2. Descriptive statistics

\begin{tabular}{lcccc}
\hline Variables & Min & Max & Mean & SD \\
\hline Profitability (\%) & -55.5 & 19.5 & 4.7 & 10.57 \\
Company Size (RM million) & 14 & 12,053 & 754 & 1699.47 \\
Growth opportunity (\%) & -100 & 263 & 18.9 & 42.38 \\
Tangibility (FA/TA) & 0.006 & 0.91 & 0.45 & 19.20 \\
Managerial Ownership (\%) & 0 & 64.67 & 11.5 & 169.3 \\
Bonds issue value (RM million) & 1.9 & 2,213 & 225 & 341.80 \\
\hline
\end{tabular}

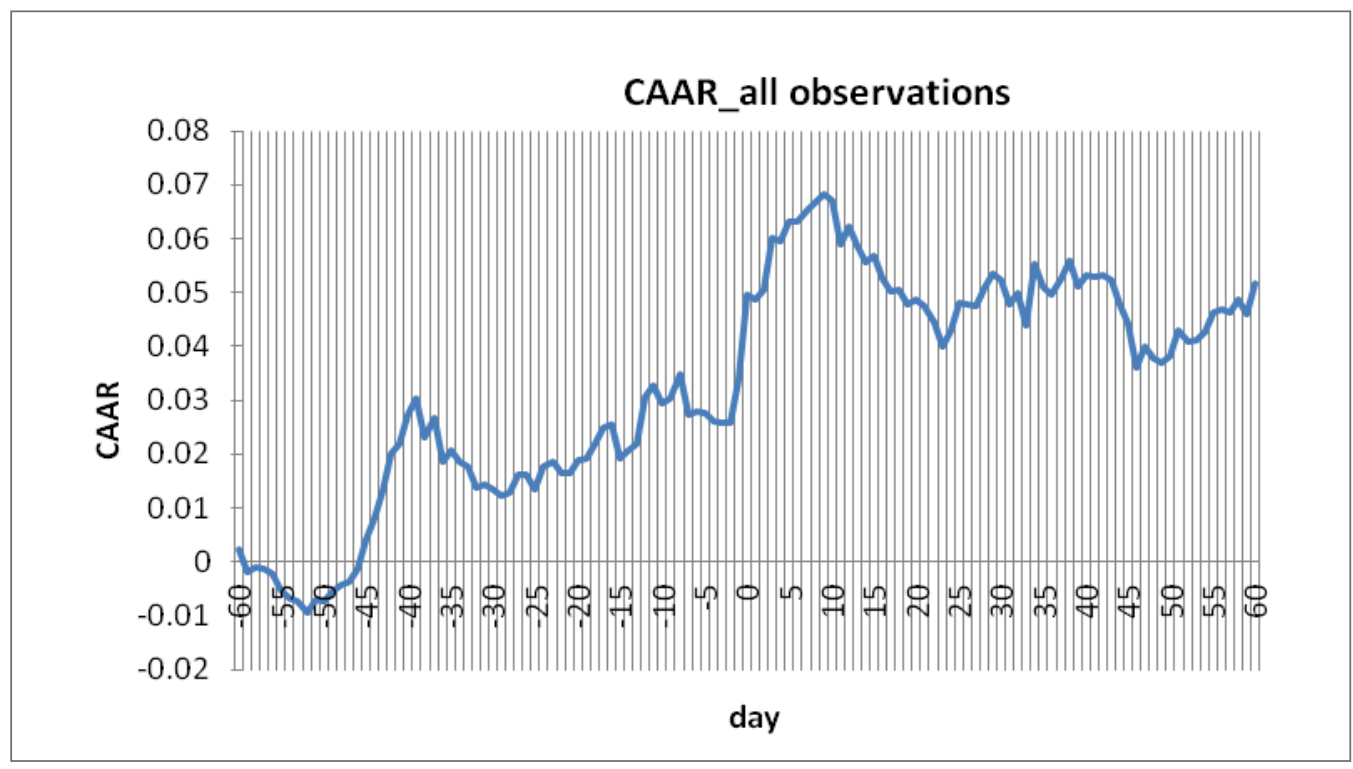

Figure 1. Graph of cumulative average abnormal returns for all observations

standard deviation, 10.57 , among the studied variables. Company size has a standard deviation of $1,699.47$, the largest value among the studied variables, and ranges from RM14 million to RM12.05 billion, with an average company size of RM754 million. Growth opportunities range from $-100 \%$ to $263 \%$, with an average growth rate of $18.9 \%$. Tangibility has a standard deviation of 19.20 and ranges from $0.6 \%$ to $91 \%$, with an average of $45 \%$. Managerial ownership ranges from $0 \%$ to $64.67 \%$, with an average of $11.5 \%$. Finally, the bond offers among the 100 sample companies range from RM1.9 million to RM2.21 billion. On average, the bond offer amount is RM225 million (USD1.00 = RM3.11).

\subsection{Event study results}

Figure 1 presents the cumulative average abnormal return (CAAR) for bond issuers. Bond issuers generally experience an increasing CAAR trend over the 60 days before $(t=-60)$ the event day or the bond issuance date $(\mathrm{t}=0)$ and over the first 10 days $(\mathrm{t}=+10)$ of the postevent period. There was a decline in CAAR from 60 days to 55 days before the event date when there were abnormal losses. Thereafter, the cumulative average abnormal return surged to a positive value starting from day $\mathrm{t}=-45$, fluctuated between $1 \%$ and $3 \%$, and finally increased substantially after day $t=-1$, one day prior to the event day. After the event day, the CAAR 
continued to rise for three days and finally reached a peak of $6.84 \%$ on day $t=+9$. However, immediately after the ninth day, the CAAR began to show a declining trend, dropping to a low of $4 \%$ at day $\mathrm{t}=+23$. The CAAR rose again after day $\mathrm{t}=+24$ and fluctuated between $4.5 \%$ and $5.5 \%$ until 45 days $(t=+45)$ after the issuance date, but failed to be sustained thereafter.

To examine the null hypothesis of whether there are significant cumulative average abnormal returns, a ttest is carried out over different intervals and the result is shown in Table 3. Overall, bond issuers enjoy a significant positive cumulative average abnormal return 10 days after the issuance date and 21 days surrounding the event day at the $\alpha=0.10$ and $\alpha=0.05$ levels, rejecting the null hypothesis. A positive relationship between bond issuance and equity market return implies that increasing the leverage position of a company can have a positive impact on stock prices. The favorable information content and signal could also be attributed to the use of the funds from the bond instruments that are generally meant for productive purposes such as company growth and expansion. In summary, the equity market appears to generally react positively to the issuance of bonds.

A significant and positive cumulative average abnormal return 21 days surrounding the bond issuance date explains the signaling model of Ross (1977), which suggests that increased debt levels convey positive news. Market participants perceive that higher debt levels show insiders' confidence that future cash flows will increase to service the higher debt levels. Furthermore, Ross's (1977) signaling model also states that the information asymmetry between a company and outsiders leads the former to make certain changes in its capital structure that could change the relative position and/or power of capital providers (e.g., stockholders and debtors). Thus, the equity market reacts according to the changing capital structure. The finding of this study does not support the implication of Myers and Majluf's (1984), and Miller and Rock's (1985) asymmetric information model, which suggests that an announcement of external financing signals that a company's stock is overvalued, causing negative stock price reactions. In contrast, the higher leverage is a signal that a company is confident about its ability to meet interest obligations and thereby indicates its ability to generate future cash flows, which ultimately translates into a higher company value. This result contradicts the studies of Abhyankar and Dunning (1999), Ammann et al. (2006) and Chen et al. (2005), who found negative bond issuance effects. Nevertheless, the positive abnormal returns support the findings of De Roon and Veld (1998), and Martel and Padron (2006), who demonstrated that the market reacts positively and significantly to debt issue announcements.

\subsection{Cross-sectional regression results}

Both correlation and multiple regression techniques are used to examine the relationship between bond issuance effects and company characteristics. The correlation matrix in Table 4 shows that company profitability, growth opportunities, asset tangibility, company size, and ownership structure are not associated with cumulative abnormal returns. However, there is a significant correlation of $-0.692(\alpha<0.01)$ between PROFITABILITY and TANGIBILITY, and of 0.413 $(a<0.01)$ between PROFITABILITY and SIZE_LN. Nevertheless, all associations are less than 0.70. Thus, it is likely that collinearity between the independent variables poses no threat to this study.

To ensure that no multicollinearity problem exists, tolerance statistics and variance inflation factors (VIFs) are calculated and reported in Table 5. Although the target value is largely debated, a tolerance value of 0.50 or higher is generally considered to be acceptable. In terms of the VIF statistic, some researchers use a VIF of five as a critical threshold whereas others use a VIF of 10 . Based on these guidelines, the multicollinearity problem is not a threat in this study.

Table 6 presents the findings of the multiple regression analysis. The lack of correlation of the explanatory variables with the dependent variable is further supported, whereas the F-test shows an insignificant model, indicating a weak influence of company characteristics on the bond issuance effect. The R-squared value of $4.4 \%$ also implies the lack of power of the company profitability, tangibility, growth opportunity, size, and ownership structure variables to explain the variation in cumulative abnormal returns. In other words, the finding implies that the positive effect of the abnormal returns is solely caused by the bond issuance announcement. Hence, investors could buy the stock of a bond issuer to gain abnormal returns. However, this is only possible by investing in approximately 100 companies. 
Table 3. T-test over different CAAR intervals

\begin{tabular}{cccc}
\hline Interval & CAAR & Interval & CAAR \\
\hline-5 to -1 & $0.59 \%$ & -30 to -1 & $1.93 \%$ \\
+1 to +5 & $1.37 \%$ & +1 to +30 & $3.29 \%$ \\
-5 to +5 & $3.54 \%$ & -30 to +30 & $3.80 \%$ \\
-10 to -1 & $0.12 \%$ & -40 to -1 & $1.19 \%$ \\
+1 to +10 & $1.74 \% *$ & +1 to +40 & $3.38 \%$ \\
-10 to +10 & $3.42 \% * *$ & -40 to +40 & $3.14 \%$ \\
-20 to -1 & $1.74 \%$ & -60 to -1 & $38 \%$ \\
+1 to +20 & $-0.09 \%$ & +1 to +60 & -60 to +60 \\
-20 to +20 & $3.22 \%$ & & $5.16 \%$ \\
\hline
\end{tabular}

** significant at $a=0.05 ;{ }^{*}$ significant at $a=0.10$

Table 4. Correlation matrix

\begin{tabular}{cccccc}
\hline & CAR & PROFITABILITY & TANGIBILITY & GROWTH & SIZE_LN \\
\hline PROFITABILITY & -0.040 & - & - & - & - \\
TANGIBILITY & 0.039 & $-0.692^{* * *}$ & - & - & - \\
GROWTH & -0.025 & 0.156 & -0.088 & -0.024 & - \\
SIZE_LN & -0.051 & $0.413^{* * *}$ & $-0.250^{*}$ & 0.026 & $-0.405^{* * *}$ \\
OWNER_LN & -0.064 & -0.047 & 0.145 & 0.06 \\
\hline
\end{tabular}

*** significant at $a=0.01 ; *$ significant at $a=0.10$

Table 5. Multicollinearity test

\begin{tabular}{ccc}
\hline \multirow{2}{*}{ Independent variables } & \multicolumn{2}{c}{ Collinearity statistics } \\
\cline { 2 - 3 } & Tolerance & VIF \\
\hline PROFITABILITY & .835 & 1.172 \\
TANGIBILITY & .970 & 1.031 \\
GROWTH & .992 & 1.008 \\
SIZE_LN & .725 & 1.380 \\
OWNER_LN & .811 & 1.233 \\
\hline
\end{tabular}


Table 6. Multiple regression

\begin{tabular}{cccc}
\hline & \multicolumn{2}{c}{ Standardized Coefficient } & Sig. \\
\hline Beta & -0.100 & -0.827 & 0.411 \\
\hline PROFITABILITY & 0.135 & 1.196 & 0.236 \\
TANGIBILITY & -0.024 & -0.218 & 0.828 \\
GROWTH & -0.067 & -0.514 & 0.609 \\
SIZE_LN & -0.115 & -0.927 & 0.357 \\
OWNER_LN & & & \\
Adjusted R2 & 0.044 & & \\
F & 0.709 & & \\
\hline
\end{tabular}

Note: Dependent variable: CAR

The regression result is not consistent with the argument of Green (1984) that abnormal returns are related to future growth opportunities. Furthermore, the expected positive relationship of company size and cumulative abnormal returns as well as the expected negative relationship of company profitability and cumulative abnormal returns proposed by Stein (1992) is also not supported. Nevertheless, the results for company size and company profitability support the work of De Roon and Veld (1998), Abhyankar and Dunning (1999), Lewis et al. (1999, 2003), and Ammann et al. (2006). The findings are also consistent with Lewis et al. (2003), Abhyankar and Dunning (1999) and Ammann et al. (2006), who found an insignificant influence of growth opportunities on cumulative abnormal returns.

\section{Conclusion}

Based on 100 bond issuance announcements by listed Malaysian companies from 2000 to 2007, the findings reveal an increase in the equity returns of bond issuers. However, they are insignificant except during the 21 days surrounding the issuance date. A positive cumulative average abnormal return implies that an increase in debt has a positive effect on stock prices. This indicates that the announcement of corporate bond issues in Malaysia could serve as a market signal to investors.
In the correlation analysis, company profitability, asset tangibility, growth opportunity, size, and ownership structure do not have a significant effect on cumulative abnormal returns, which is further supported by the multiple regression analysis. None of the company characteristics could explain the variations related to the effect of corporate bond issuance announcements in Malaysia, implying that the positive cumulative abnormal returns are solely caused by the bond issuance announcements.

There are limitations of this study. First, the results could be affected by other factors. As highlighted by Davidson, Glasrock and Schwartz (1995) and Lewis et al. (2003), abnormal returns depend on the design of a corporate bond. Thus, it is recommended that the types of debt securities, as well as the design and features of debt securities, such as maturity, coupon rate, puttable or callable features, convertible or straight debts, reputation of the underwriter, and purpose of the debts and bond offers, be incorporated into future studies. Furthermore, different proxies for the independent variables used in the study could also be considered. In addition, the sample could also be aggregated based on business sector classifications. The effect of bond issuance announcements might differ for companies in different sectors. Given the small sample used in this study, this type of approach was not possible. 


\section{References}

Abdullah, N. A. H. (1999). An empirical investigation of the effect of rights issue announcements on share returns and the determinants of abnormal returns on the Kuala Lumpur Stock Exchange. Unpublished doctoral dissertation, Aston University.

Abhyankar, A., \& Dunning, A. (1999). Wealth effects of convertible bond and convertible preference share issues: An empirical analysis of the UK market. Journal of Banking and Finance, 23(7), 1043-1065.

Abor, J. (2008). Determinants of the capital structure of Ghanaian firms (AERC Research Paper No. 176). The African Economic Research Conorcium.

Agrawal, M., Kishore, R., \& Rao, H. R. (2006). Market reactions to e-business outsourcing announcements: An event study. Information and Management, 43(7), 861-873.

Altman, E., Gande, A., \& Saunders, A. (2004). Informational efficiency of loans versus bonds: Evidence from secondary market prices (Working Paper No. FIN-04-001). Stern School of Business, New York University.

Ammann, M., Fehr, M., \& Seiz, R. (2006). New evidence on the announcement effect of convertible and exchangeable bonds. Journal of Multinational Financial Management, 16(1), 43-63.

Arshanapalli, B., Fabozzi, F., Switzer, L.N., \& Gosselin, G. (2004). New evidence on the market impact of convertible bond issues in the U.S. (Working paper). Concordia University.

Bank for International Settlements (2007). Financial stability and local currency bond markets (CGFS paper No. 28). Bank for International Settlements.

Bank Negara Malaysia (2005). Annual report 2005. Retrieved from http://www.bnm.gov.my

Bank Negara Malaysia (2006). Annual report 2006. Retrieved from http://www.bnm.gov.my

Bank Negara Malaysia (2007). Annual report 2007. Retrieved from http://www.bnm.gov.my

Barclay, M. J., \& Smith, C. W. (2005). The capital structure puzzle: The evidence revisited. Journal of Applied Corporate Finance, 17(1), 8-18.

Barnes, M. L., \& Ma, S. (2001). Market efficiency or not? The behavior of China's stock prices in response to the announcement of bonus issues (Discussion paper No. 0120). Adelaide University, Australia.
Bradley, M., Jarrell, G. A., \& Kim, E. H. (1984). On the existence of an optimal capital structure: Theory and evidence. Journal of Finance, 39(3), 857-878.

Brennan, M., \& Kraus, A. (1987). Efficient financing under asymmetric information. Journal of Finance, 42(5), 1225-1243.

Brennan, M., \& Schwartz, E. (1988). The case for convertibles. Journal of Applied Corporate Finance, 1(2), 55-64.

Brown, E. (1999). Long-run performance analysis of a new sample of UK IPOs (Working Paper August 1999). University of Edinburgh.

Brown, S. J., \& Warner, J. B. (1985). Using daily stock returns, the case of event studies. Journal of Financial Economics, 14(1), 3-31.

Buferna, F. (2005). Determinants of capital structure: Evidence from Libya (Research paper series No. 2005/08). University of Liverpool.

Carlsson, P., Holm, O., \& Sello, M. (2006). Corporate hybrid capital - Expensive debt or cheap equity? (Unpublished master thesis). School of Business Economics and Law, Goteborg University, Goteborg.

Charitou, A., Vafeas, N., \& Zachariades, C. (2005). Irrational investor response to stock splits in an emerging market. The International Journal of Accounting, 40(2), 133-149.

Chen, J. J. (2004). Determinants of capital structure of Chinese-listed companies. Journal of Business Research, 57(12), 1341-1351.

Chen, C., Dong, L., \& Wen, M. M. (2005). Backdoor equity financing, firm characteristics, and shareholders' wealth. Center for China Finance \& Business Research.

Davidson, W. N, Glasrock, J. L., \& Schwartz, T. V. (1995). Signaling with convertible debt. Journal of Financial \& Quantitative Analysis, 30(3), 425-440.

Denis, D. J., \& Mihov, V. T. (2003). The choice among bank debt, non-bank private debt and public debt: Evidence from new corporate borrowings. Journal of Financial Economics, 70(1), 3-28.

De Haan, L., \& Hinloopen, J. (1999). Debt or equity? An empirical study of security issues by Dutch Companies (Research Memorandum WO\&E no. 577/9910). De Nederlandsche Bank Econometric Research and Special Studies Department. Retrieved from http://www.dnb.nl/en/binaries/ wo0577_tcm47-145906.pdf 
De Roon, F., \& Veld, C. (1998). Announcement effects of convertible bond loans and warrant-bond loans: An empirical analysis for the Dutch market. Journal of Banking and Finance, 22(12), 1481-1506.

Devic, A., \& Krstic, M. (2001). Comparable analysis of the capital structure determinants in Polish and Hungarian enterprises - empirical study. Economics and Organization, 1(9), 85-100.

Dutordoir, M., \& De Gucht, L.V. (2004). Why do Western Europe firms issue convertibles instead of straight debt or equity? (ERIM Report Series Reference No. ERS-2006-056-F\&A). Columbia University. Retrieved from SSRN: http://ssrn. com/abstract $=942151$

Eichengreen, B. (2004). Why doesn't Asia have bigger bond markets? (Working Paper No. 10576). National Bureau of Economic Research.

Fama, E. F.(1998). Market efficiency, long-term returns, and behavioral finance. Journal of Financial Economics, 49(3), 283-306.

Ferri, M. G., \& Jones, W. H. (1979). Determinants of financial structure: A new methodological approach. Journal of Finance, 34(3), 631-644.

Gao, Y., \& \& Tse, Y.K. (2003). Market segmentation and information value of earnings announcements: Some empirical evidence from an event study on the Chinese stock market. (Unpublished working paper).

Gaud, P., Jani, E., Hoesli, M., \& Bender, A. (2005). The capital structure of Swiss companies: An empirical analysis using dynamic panel data. European Financial Management, 11(1), 51-69.

Gebhardt, W.R., Hvidkjaer, S., \& Swaminathan, B. (2005). Stock and bond market interaction: Does momentum spill over? Journal of Financial Economics, 75(3), 651-690.

Green, R. (1984). Investment incentives, debt and warrants. Journal of Financial Economics, 13(1), $115-136$

Guha, K. B., \& Kar, S. (2006). The corporate debt market. A firm-level panel study for India (Research paper No. 2006/50). World Institute for Development Economics Research.

Hovakimian, A., Opler, T., \& Titman, S. (2001). The debt equity choice. Journal of Financial Quantitative Analysis, 36(1), 1-24.

Hovakimian, A., Hovakimian, G., \& Tehranian, H. (2004). Determinants of target capital structure:
The case of dual debt and equity issues. Journal of Financial Economics, 71, 517-40.

Ibrahim, M., \& Wong, A. (2005). The corporate bond market in Malaysia (BIS Paper No. 26, February). Bank for International Settlements. Retrieved from http://www.bis.org/publ/bppdf/ bispap26p.pdf

Isachenkova, N., \& Mickiewicz, T. (2004). Ownership characteristics and access to finance. Evidence from a survey of large privatized companies in Hungary and Poland (Working Paper No. 666). William Davidson Institute.

Jensen, M. (1986). Agency costs of free cash flow, corporate finance and takeovers. American Economic Review, 76(2), 323-339.

Kang, J. K., Kim, Y. C., Park, K. J., \& Stulz, R. M. (1995). An analysis of the wealth effects of Japanese offshore dollar-denominated convertible and warrant bond issues. The Journal of Financial and Quantitative Analysis, 30(2), 257-270.

Kapoor, A. K., \& Pope, R. A. (1997). The relationship between corporate debt issuance and changes in systematic risk. Journal of Financial \& Strategic Decision, 10(3), 13-22.

Kim Y. C., \& Stulz, R. M. (1992). Is there a global market for convertible bonds? Journal of Business, 65(1), 75-91.

Kothari, S. P., \& Warner, J. B. (2007). Econometrics of event studies. In B. E. Eckbo (Ed.), Handbook of Corporate Finance, (Vol. 1 pp. 3-36). Amsterdam: North Holland Elsevier.

Lee, J-W., Lee, Y. S., \& Lee, B-S. (2000). The determination of corporate debt in Korea. Asian Economic Journal, 14(4), 333-356.

Lewis, C. M., Rogalski, R. J., \& Seward, J. K. (1999). Is convertible debt a substitute for straight debt or for common equity? Financial Management 28(3), 5-27.

Lewis, C. M., Rogalski, R. J., \& Seward, J. K. (2001). The long-run performance of firms that issue convertible debt: An empirical analysis of operating characteristics, analyst forecasts, and risk effects. Journal of Corporate Finance, 7(4), 447-474.

Lewis, C.M., Rogalski, R.J., \& Seward, J.K. (2003). Industry conditions, growth opportunities and market reaction to convertible debt financing decisions. Journal of Banking and Finance, 27(1), 153-181. 
Luengnaruemitchai, P., \& Ong, L. L. (2005). An anatomy of corporate bond markets: Growing pains and knowledge gains (Working Paper No. 05/152). International Monetary Fund.

MacKinlay, A. C. (1997). Event studies in economics and finance. Journal of Economics Literature, 35(1), 13-39.

Martel, M. C. V., \& Padron, Y. G. (2006). Debt and information content: Evidence in the Spanish stock market. International Research Journal of Finance \& Economics, Issue 4 (July 2006), 202-208.

Masulis, R. W. (1983). The impact of capital structure change on firm value: Some estimates. Journal of Finance, 38, 107-126.

Miller, M., \& Rock, K. (1985). Dividend policy under asymmetric information. Journal of Finance, 40(4), 1031-1051.

Modigliani, M., \& Miller, M. (1958). The cost of capital, corporation finance and the theory of investment. The American Economic Review, 48(3), 261-297.

Modigliani, M., \& Miller, M. (1963). Corporate income taxes and the cost of capital: A correction. American Economic Review, 53(3), 433-443.

Mollemans, M. (2002). The convertible bond announcement effect in Japan (Working paper No. 1f). Macquarie University, Sydney, Australia.

Myers, S., \& Majluf, N. (1984). Corporate financing and investment decisions when firms have information that investors do not have. Journal of Financial Economics, 13(2), 187-222.

Navarrete, A. F. (2001). The role of the corporate bond market in Mexico as a source of financing. Paper presented at conference on Financial Markets in Mexico, Center for Research on Economic Development and Policy Reform, Stanford University, October 3-6, 2001, Stanford, CA.

Pandey, I. M. (2004). Capital structure, profitability and market structure: Evidence from Malaysia. Asia Pacific Journal of Economics \& Business, 8(2), 78-91.

Rajan, R. G., \& Zingales, L. (1995). What do we know about capital structure? Some evidence from international data. Journal of Finance, 50(5), 14211460.

Ross, S. A. (1977). The determination of financial structure: The incentive-signaling approach. Bell Journal of Economics, 8(1), 23-40.
Schramade, W. (2005). Bond market entry and agency costs of equity [draft]. RSM Erasmus University, The Netherlands.

Soongswang, A. (2007). An investigation of tender offer effects on Thai target firms during the bid period. International Research Journal of Finance \& Economics, Issue 9 (2007), 88-104.

Stein, J. C. (1992). Convertible bonds as backdoor equity financing. Journal of Financial Economics, 32(1), 3-21.

Titman, S., \& Wessel, R. (1988). The determinants of capital structure choice. Journal of Finance, 43(1), 1-19.

Wiwattanakantang, Y. (1999). An empirical study on the determinants of the capital structure of Thai firms. Pacific-Basin Finance Journal, 7(3-4), 371-403.

\section{Acknowledgements}

We would like to extend our appreciation to the Universiti Utara Malaysia for funding this research project through the Post Graduate Research Development Incentive Program. We are also grateful to the constructive comments provided by the discussant and participants of the $13^{\text {th }}$ Malaysian Finance Association Conference 2011. 
